\title{
Increased chemoresistance to paclitaxel in the MCF10AT series of human breast epithelial cancer cells
}

\author{
SOO-JEONG LIM ${ }^{1}$, HYEON GYEOM CHOI ${ }^{2}$, CHAE KYUNG JEON $^{3}$ and SO HEE KIM ${ }^{4}$ \\ ${ }^{1}$ Department of Bioscience and Biotechnology, Sejong University, Seoul; ${ }^{2}$ College of Natural Science, Hannam University, \\ Daejeon, Republic of Korea; ${ }^{3}$ Grinnell College, Grinnell, IA, USA; ${ }^{4}$ College of Pharmacy and Research Institute \\ of Pharmaceutical Science and Technology, Ajou University, Suwon, Republic of Korea
}

Received November 19, 2014; Accepted December 29, 2014

DOI: $10.3892 /$ or.2015.3775

\begin{abstract}
The MCF10AT cell series of human breast epithelial cancer cells includes normal MCF10A (10A), premalignant MCF10AT (10AT) and MCF10ATG3B (10ATG3B), and fully malignant MCF10CA1a (10CA1a) cells. The series is a unique model system showing progressive tumorigenic potential with the same origin. The effects of paclitaxel, a microtubule inhibitor, were evaluated in this cell system. Paclitaxel inhibited cell proliferation in a time-dependent $(24,48$ and $72 \mathrm{~h}$ ) and concentration-dependent (0-10 nM) manners with less sensitivity in 10CA1a cells. Treatment with paclitaxel $(10 \mathrm{nM})$ for $24 \mathrm{~h}$ induced apoptosis in 10A, 10AT, 10ATG3B and 10CA1a cells, with 23.6, 26.1,25.2 and 8.96\%, respectively, in the sub- $\mathrm{G}_{1}$ phase. Treatment with paclitaxel $(0-10 \mathrm{nM})$ for $24 \mathrm{~h}$, resulted in the appearance of DNA fragmentation (a hallmark of apoptosis) with less sensitivity in the 10CA1a tumor cells. Paclitaxel increased p53 protein expression in 10A, 10AT, 10ATG3B and 10CA1a cells, by 87, 102, 812 and $84 \%$, respectively. The $\mathrm{p} 21^{\text {Waf } 1 / \text { Cipl }}$ protein expression increased by $2.57-, 1.53$ - and 2.48 -fold in 10A, 10AT and 10ATG3B cells, respectively, with negligible detection in the 10CA1a cells. Activation of the Akt signaling pathway was observed in the MCF10AT cell lineage and the protein expression of phospho-Akt (Ser473 and Thr308). The downstream targets of this pathway, phospho-p70S6K and phospho-S6RP, were also inhibited by paclitaxel in 10A, 10AT and 10ATG3B cells, but minimally inhibited in 10CA1a cells, suggestive of chemoresistance in 10CAla cells. The effects of paclitaxel on the multidrug resistance $1(M D R 1), M R P 1$ and breast cancer resistance protein $(B C R P)$ gene expression were not significant in the MCF10AT cell lineage. These results collectively indicated that paclitaxel inhibited cell proliferation and induced
\end{abstract}

Correspondence to: Dr So Hee Kim, College of Pharmacy and Research Institute of Pharmaceutical Science and Technology, Ajou University, 5 Woncheon-dong, Suwon 443-749, Republic of Korea E-mail: shkim67@ajou.ac.kr

Key words: MCF10AT cell lineage, paclitaxel, apoptosis, $\mathrm{p} 21^{\text {Wafl/Cipl }}$, p53, Akt, chemoresistance apoptosis in the MCF10AT cell lineage, with chemoresistance in 10CA1a tumor cells. The decreased responsiveness to paclitaxel observed in 10CA1a tumor cells was likely due, in part, to activation of the Akt signaling pathway and a high expression of wild-type $\mathrm{p} 53$ with lack of $\mathrm{p} 21^{\text {Wafl/Cip1 }}$.

\section{Introduction}

Breast cancer is a major leading cause of mortality among women in the US, and the risk for developing breast cancer in American women is estimated as one in seven (1). The MCF10AT series of human breast epithelial cell lines is a system that consists of a series of cell lines with progressively increasing tumorigenic potential. This cell series includes the benign MCF10A (10A), premalignant MCF10AT (10AT) and MCF10ATG3B (10ATG3B), and fully malignant MCF10CA1a (10CA1a) cells (2). These breast cell lines, derived from the same patient with benign fibrocystic disease (3), are a unique system with common genetic features. The cells were utilized to examine early and progressive alterations in signaling proteins that occur in the cells ranging from benign to transformed/slowly tumorigenic, to high-risk transformed/hyperplastic and sporadically tumorigenic, to fully malignant cells $(4,5)$.

Paclitaxel was isolated from the bark of the Pacific yew tree, Taxus brevifolia (6). It was initially approved for use in advanced ovarian cancer and subsequently for the treatment of metastatic breast cancer (7). Paclitaxel is currently used against a wide range of solid tumors, including urothelial, breast, ovarian and lung cancers (8). The antitumor effects of paclitaxel may result from interference with the normal function of microtubules and from blocking cell-cycle progression in the late $\mathrm{G}_{2}-\mathrm{M}$ phase (9). Paclitaxel induces apoptosis that is mediated through $\mathrm{G}_{2}-\mathrm{M}$ arrest and DNA fragmentation (10). However, it was shown that paclitaxel-induced apoptosis may occur without a prior $\mathrm{G}_{2}-\mathrm{M}$ arrest (11), instead in the $\mathrm{G}_{1}-\mathrm{S}$ stages. Intrinsic and acquired drug resistance to paclitaxel are serious issues that arise during therapy (12). Many factors are involved in drug resistance, including mutations in $\alpha$ and $\beta$ tubulin, differing compositions of $\beta$-tubulin isotypes, overexpression of multidrug resistance-associated proteins, such as P-glycoprotein (P-gp), breast cancer resistance protein (BCRP), multidrug resistance-associated protein (MRP), and increased microtubule dynamics with altered 
microtubule-associated protein $\tau\left(\mathrm{MAP}_{\tau}\right)$ expression (13). Therefore, functional aberrations in molecular pathways, such as cell-cycle control, growth promotion and apoptosis can contribute to chemoresistance (14).

We previously reported a progressive increase in Ras protein levels and proteins involved in the phosphatidylinositol 3-kinase (PI3K)/Akt signaling pathway (4) and resistance to rapamycin in this cell lineage (5). Starcevic et al reported resistance to Fas-mediated apoptosis (15), and decreased sensitivity to oxidative DNA damage by $\mathrm{H}_{2} \mathrm{O}_{2}$ with increased risk of tumorigenicity in the same cell lineage (16). The purpose of the present study was to evaluate the effects of paclitaxel, including cell proliferation, apoptosis and cell cycle arrest in benign, premalignant and tumor cells of the MCF10AT human breast epithelial cell lineage. We also examined whether these human breast epithelial cancer cells developed chemoresistance to paclitaxel.

\section{Materials and methods}

Human breast epithelial cell lines. The 10A, 10AT, 10ATG3B and 10CA1a cell lines were obtained from Dr Novak and Dr Miller at the Karmanos Cancer Institute (Detroit, MI, USA). Benign 10A cells, the progenitor line of the $10 \mathrm{~A}$ series, are spontaneously immortalized breast epithelial cells obtained from a female patient with fibrocystic breast disease (3). The $10 \mathrm{~A}$ cells were transfected with a mutated $\mathrm{T}_{24} \mathrm{Ha}$-ras gene to generate premalignant 10AT cells $(17,18)$. The premalignant 10ATG3B cell line was generated from 10AT cells that underwent this process of transplantation in nude/beige mice and re-establishment in culture three times (2). The 10ATG3B cells were more tumorigenic than 10AT cells. The fully malignant 10CA1a cell line was generated from a xenograft obtained from sequential passages by trocar transplantation (19). The 10CA1a cell line led to rapidly growing tumors with $100 \%$ efficacy.

Cell culture. The cells were cultured in Dulbecco's modified Eagle's medium/F-12 medium supplemented with $10 \mathrm{mg} / \mathrm{ml}$ of human insulin, $20 \mathrm{ng} / \mathrm{ml}$ of epidermal growth factor (all from Invitrogen, Carlsbad, CA, USA), $0.5 \mathrm{mg} / \mathrm{ml}$ of hydrocortisone (Sigma-Aldrich, St. Louis, MO, USA), $5 \%$ horse serum, $100 \mathrm{U} / \mathrm{ml}$ of penicillin and $100 \mathrm{mg} / \mathrm{ml}$ of streptomycin (both from Invitrogen). The cells were maintained in a humidified environment of $5 \% \mathrm{CO}_{2} / 95 \%$ air at $37^{\circ} \mathrm{C}$ as previously described $(4,5)$. The $80 \%$ confluent cells were filtered in $60 \mathrm{~mm}^{2}$ tissue culture dishes.

Antibodies. Antibodies against retinoblastoma (Rb), its phosphoproteins, poly(ADP-ribose) polymerase (PARP),E2F1, Bax, cyclin A, phospho-Akt (Ser473 and Thr308), phospho-p70S6K (Thr421/Ser424 and Thr389), phospho-S6RP, cyclin-dependent kinase (cdk) 2, p21 Wafl/Cip1 $^{\text {and }}$ p27 $7^{\text {Kipl }}$ were obtained from Cell Signaling Technology (Beverly, MA, USA). p53 antibody was purchased from Santa Cruz Biotechnology, Inc. (Santa Cruz, CA, USA) and cyclin D3 antibody was purchased from BD Transduction (San Jose, CA, USA). Anti-glyceraldehyde-3-phosphate dehydrogenase (GAPDH) antibody was obtained from Calbiochem (EMD Biosciences Inc., San Diego, CA, USA).
Cell proliferation assay. The effect of paclitaxel (SigmaAldrich) on cell proliferation was tested in cells plated on flat-bottomed 24 -well plates at a density of $1-2 \times 10^{4}$ cells/well in 1-ml medium and determined on the basis of growth characteristics. Triplicate wells were treated with varying concentrations of paclitaxel for 24,48 and $72 \mathrm{~h}$ following overnight incubation. The relative percentage of metabolically active cells to untreated controls was then determined on the basis of the mitochondrial conversion of 3-(4,5-dimethylthiazol-2-yl)-2,5-diphenyltetrazolium bromide to formalin. The ability of cells to form formalin by active mitochondrial respiration was detected using a 96-well format plate reader by measuring the absorbance at a wavelength of $550 \mathrm{~nm}$ $\left(\mathrm{A}_{550 \mathrm{~nm}}\right)$. The percentage of metabolically active cells was compared with the percentage of control cells growing in the absence of paclitaxel in the same culture plate. The percentage of inhibition was calculated by the formula: $\%$ inhibition $=$ $\left(\mathrm{OD}_{\text {control }}-\mathrm{OD}_{\text {test }} / \mathrm{OD}_{\text {control }}\right) \times 100(20)$.

DNA fragmentation assay. Each cell of the MCF10AT cell lineage $\left(1 \times 10^{4} /\right.$ well $)$ was treated with $0,1,2,5$ and $10 \mathrm{nM}$ paclitaxel for $24 \mathrm{~h}$ in 96-well plates containing medium with $1 \%(\mathrm{v} / \mathrm{v})$ horse serum in a humidified environment of $5 \%$ $\mathrm{CO}_{2} / 95 \%$ air at $37^{\circ} \mathrm{C}$. Cytoplasmic DNA fragments, which are an indicator of apoptosis, were measured with a DNA cell death detection ELISA ${ }^{\text {PLUS }}$ kit (Roche Diagnostics GmBH, Mannheim, Germany) according to the manufacturer's instructions.

Flow cytometry. The cells were treated with $10 \mathrm{nM}$ paclitaxel for 24 and $48 \mathrm{~h}$, harvested in $0.25 \%$ trypsin/0.1\% EDTA (in phosphate-buffered solution), centrifuged for $5 \mathrm{~min}$ at $500 \mathrm{x} \mathrm{g}$ and $4{ }^{\circ} \mathrm{C}$, washed and fixed with $75 \%$ ethanol and then resuspended in $1 \mathrm{ml}$ of propidium iodine staining solution (i.e., $50 \mu \mathrm{g} / \mathrm{ml}$ of propidium iodide, $100 \mathrm{U} / \mathrm{ml}$ of ribonuclease A and $0.1 \%$ glucose) for $1 \mathrm{~h}$. Apoptotic cells were quantified on the FACSCalibur flow cytometer and identified using Cell Quest software (Becton-Dickinson, San Jose, CA, USA). Red fluorescence, measured at 585/542 nm, indicative of propidium iodide uptake by damaged cells, was measured by logarithmic amplification and electronic compensation for spectral overlap (21).

Immunoblot analysis. The cells were treated with $10 \mathrm{nM}$ paclitaxel for 24 and/or $48 \mathrm{~h}$, and subsequently lysed. Protein concentrations were determined as previously described (22). Protein samples (20-40 $\mu \mathrm{g}$ of protein/lane) from three dishes of cells were resolved by sodium dodecyl sulfate-polyacrylamide gel electrophoresis (SDS-PAGE) on a gel (7.5-15\%) and transferred to nitrocellulose. Blots were incubated with the appropriate diluted primary antibody in $5 \%$ bovine serum albumin (BSA), Tris-buffered saline (TBS) and $0.1 \%$ Tween-20 (TBS-T) at $4{ }^{\circ} \mathrm{C}$ with gentle agitation, overnight, followed by incubation with a secondary antibody conjugated to horseradish peroxidase for $2 \mathrm{~h}$ at room temperature for immunodetection. Protein expression was detected by enhanced chemiluminescence (Amersham Life Science, Piscataway, NJ, USA) on Kodak X-OMAT film (Sigma). Exposed film was scanned and the band density was quantified by Kodak 1D Image Analysis (Eastman Kodak Company, Rochester, NY, USA). GAPDH was used as an internal standard. 

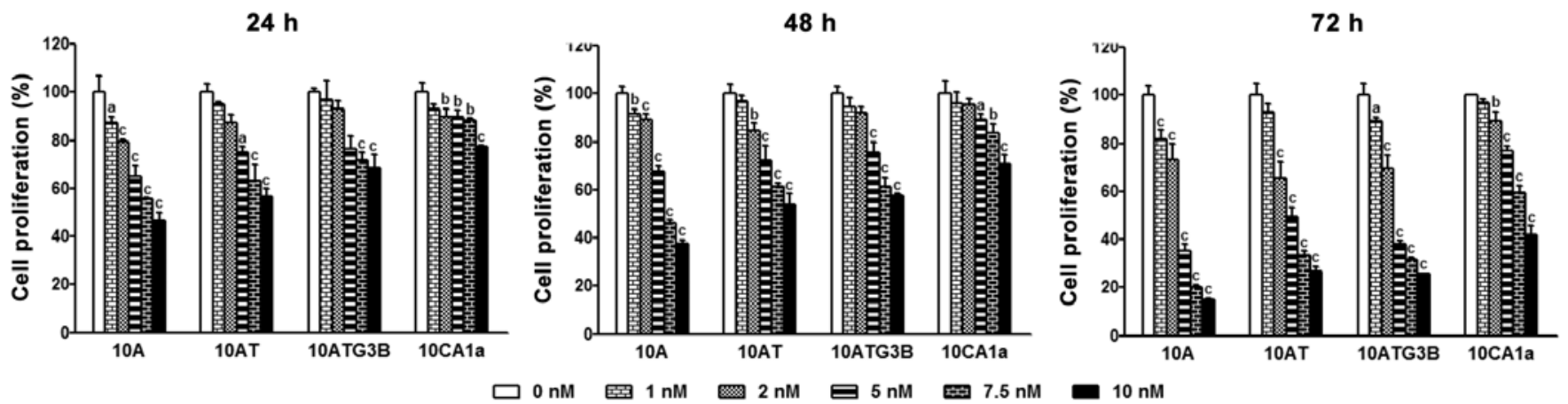

Figure 1. Inhibition of cell growth by paclitaxel. MCF10AT cell lineage was treated with paclitaxel at the indicated concentrations for 24,48 and $72 \mathrm{~h}$ and cell viability was determined by a standard 3-(4,5-dimethylthiazol-2-yl)-2,3-diphenyltetrazolium bromide assay. Columns and error bars show the means \pm standard deviation (SD) of three separate experiments at each treatment dose. ${ }^{a} \mathrm{P}<0.05 ;{ }^{b} \mathrm{P}<0.01 ;{ }^{\mathrm{c}} \mathrm{P}<0.001$. Cells were significantly different from each untreated control $(0 \mathrm{nM})$.

$M R P 1, M D R 1$ and BCRP expression. Total cellular RNA was isolated from cells with TRIzol reagent (Invitrogen) and purified with an RNeasy mini kit (Qiagen, Valencia, CA, USA). Single-stranded oligo(dT)-primed cDNA was generated from $2 \mu \mathrm{g}$ total RNA using RNA reverse transcriptase (Applied Biosystems, Foster City, CA, USA). The quantitative reverse transcribed PCR (RT-qPCR) reaction was prepared using the Power SYBR-Green Master Mix and RT-qPCR was performed with the StepOnePlus Real-Time PCR system (both from Applied Biosystems). The semi-quantitative RT-PCR reaction was prepared using GoTaq $^{\circledR}$ PCR Master Mix (Promega, Madison, WI, USA). Each sample had a final volume of $15 \mu \mathrm{l}$ containing $100 \mathrm{ng}$ of cDNA. Primers used for analysis of human MDR1, MRPI and BCRP were: $M D R 1$ (forward, 5'-AAG CCA CGT CAG CTC TGG ATA-3' and reverse, 5'-CGG CCT TCT CTG GCT TTG T-3', 73 bp); MRP1 (forward, 5'-AAG AAA ACA GGG AAG CAG CA-3' and reverse, 5'-GCT CTC TGG GTT TGA AGT CG-3', $150 \mathrm{bp}$ ); $B C R P$ (forward, 5'-CCC GCG ACA GTT TCC AAT GA-3' and reverse, 5'-GGC GTT GAG ACC AGG TTT CA-3', $171 \mathrm{bp}$ ); and GAPDH (forward, 5'-GTC AAC GGA TTT GGT CGT ATT-3' and reverse, 5'-AGT CTT CTG GGT GGC AGT GAT-3'). GAPDH was used as an internal standard. The amplification reaction was carried out with $2 \mu 1$ of cDNA product for 40 cycles; each cycle consisted of $95^{\circ} \mathrm{C}$ for $30 \mathrm{sec}, 60^{\circ} \mathrm{C}$ for $30 \mathrm{sec}$, and $72^{\circ} \mathrm{C}$ for $30 \mathrm{sec}$, followed by a final 1-min elongation at $72^{\circ} \mathrm{C}$. Relative mRNA levels were assessed using the $2^{-\Delta \Delta \mathrm{Ct}}$ method or $1.5 \%$ agarose gel electrophoresis.

Statistical analysis. Data were presented as means \pm standard deviation. Statistical significance $(\mathrm{P}<0.05)$ between groups was determined by analysis of variance (ANOVA), followed by the Tukey-Kramer multiple comparison analysis $(4,5)$.

\section{Results}

Cell proliferation of the MCF10AT cell lineage. Paclitaxel differentially inhibited cell proliferation of 10A, 10AT, 10ATG3B and 10CA1a cells in a time-dependent $(24,48$ and $72 \mathrm{~h}$ ) and concentration-dependent (0-10 $\mathrm{nM})$ manner as determined by the MTT assay (Fig. 1). Paclitaxel treatment at $10 \mathrm{nM}$ for $48 \mathrm{~h}$ inhibited 10A, 10AT and 10ATG3B cell proliferation by $62.3,46.2$ and $42.3 \%$, respectively. However, paclitaxel inhibited 10CA1a cell proliferation by $29.2 \%$ at $48 \mathrm{~h}$, showing that the 10CA1a tumor cells were less sensitive to paclitaxel than the benign (10A) and premalignant (10AT and 10ATG3B) cells $(\mathrm{P}<0.01$, Fig. 1). The same pattern of inhibition by paclitaxel was also observed at 24 and $72 \mathrm{~h}$ (Fig. 1).

Cell cycle analysis. We determined whether paclitaxel induced apoptosis and cell cycle arrest of the MCF10AT cell series. Paclitaxel differentially arrested the cell-cycle progression of the MCF10AT cell series at the subG $\mathrm{G}_{1} / \mathrm{G}_{1}$ phase (Fig. 2). The treatment of MCF10AT cell lineage with $10 \mathrm{nM}$ paclitaxel for $24 \mathrm{~h}$ induced the apoptosis of cells in sub- $\mathrm{G}_{1}$ phase by $23.6,26.1,25.2$ and $8.96 \%$ in 10A, 10AT, 10ATG3B and 10CA1a, respectively, showing less sensitivity in 10CA1a cells. However, treatment with $10 \mathrm{nM}$ paclitaxel for $48 \mathrm{~h}$ resulted in the progression to $\mathrm{G}_{1} / \mathrm{S}$-phase arrest. The percentage of cells in the $\mathrm{G}_{1}$ phase increased by 27.6 and $26.7 \%$ in premalignant $10 \mathrm{AT}$ and 10ATG3B cells as compared to the control at $24 \mathrm{~h}$, while the corresponding values in the $\mathrm{S}$ phase decreased by 11.3 and $19.8 \%$ (Fig. 2). $G_{1}$ arrest by paclitaxel was prominent in the 10AT and 10ATG3B premalignant cells at $48 \mathrm{~h}$ and 20.2 and $10.2 \%$ apoptosis was consistently detected in 10A and 10CA1a cells, respectively, at $48 \mathrm{~h}$ (Fig. 2). These results indicated that paclitaxel inhibited cell proliferation through cell-cycle arrest from the subG $\mathrm{G}_{1}$ to $\mathrm{G}_{1}$ phase at $24 \mathrm{~h}$ and from $\mathrm{G}_{1}$ to $\mathrm{S}$ phase at $48 \mathrm{~h}$ in the MCF10AT cell lineage, which was accompanied by a decrease in S-phase progression. Additionally, the 10CA1a tumor cells were more resistant to paclitaxel-mediated cell cycle arrest (Fig. 2).

Measurement of DNA fragmentation. The apoptotic effect of paclitaxel was confirmed by the measurement of cytoplasmic DNA fragments, the hallmark of apoptosis (Fig. 3). The cells treated with $0,1,2,5$ and $10 \mathrm{nM}$ paclitaxel for $24 \mathrm{~h}$ showed that DNA fragments increased in a concentration-dependent manner with less sensitivity in fully malignant 10CA1a cells (Fig. 3). Treatment of 10A, 10AT, 10ATG3B and 10CA1a cells with $10 \mathrm{nM}$ paclitaxel resulted in DNA fragmentation levels of $300,210,270$ and $181 \%$, respectively, as compared to each control, while the 10CA1a cells were significantly less 
A
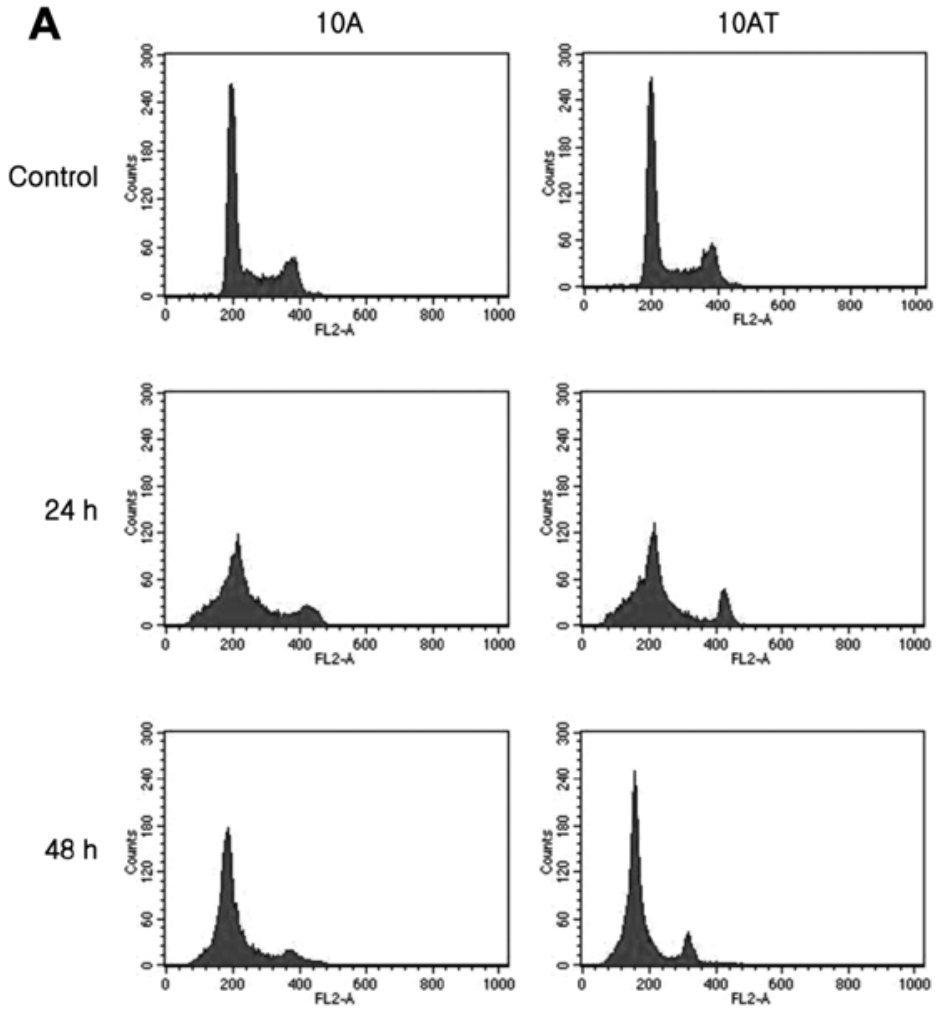
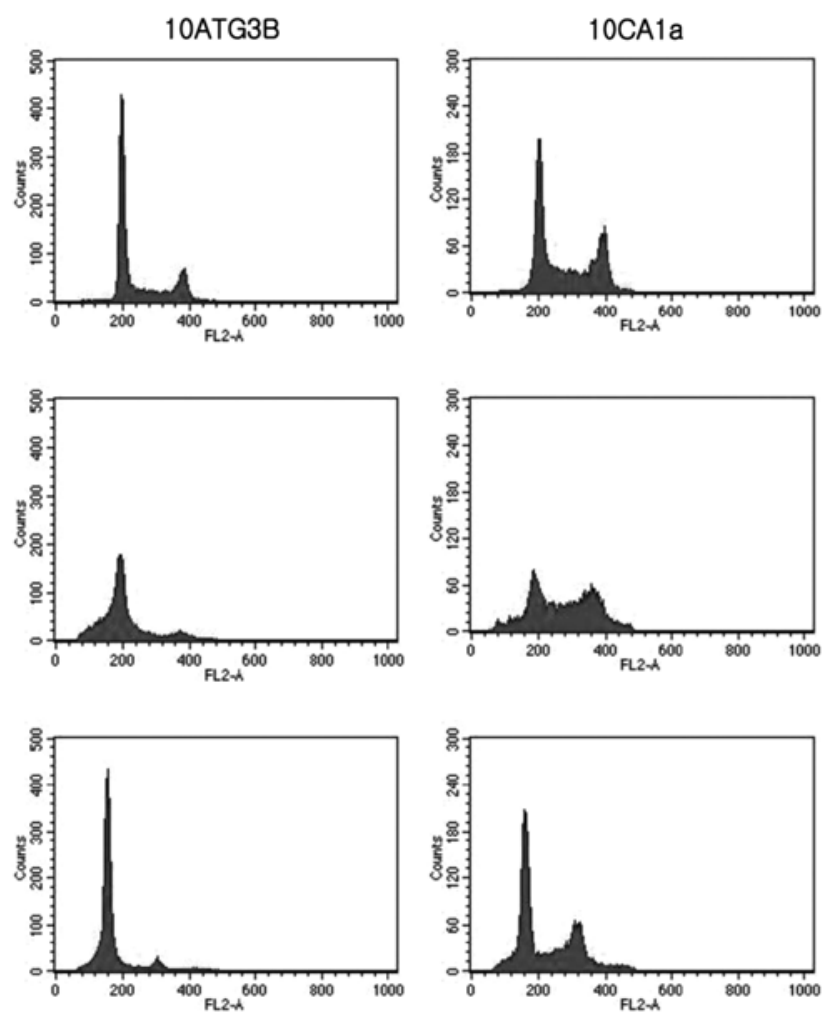

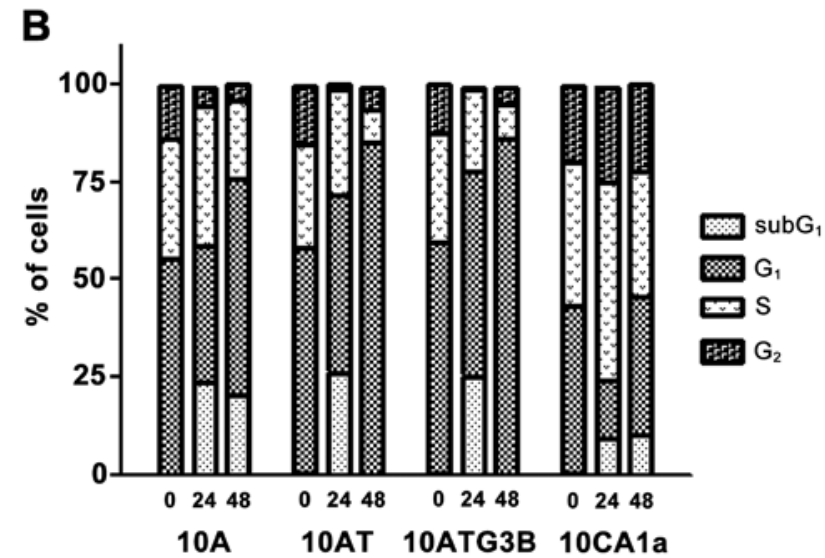

sensitive to paclitaxel than the benign and premalignant cells $(\mathrm{P}<0.05)$.

Protein expression involved in the cell cycle and Akt pathway. Immunoblot analysis results of $\mathrm{subG}_{1} / \mathrm{G}_{1}$ checkpoint protein expression at $24 \mathrm{~h}$, particularly p53 and PARP are shown in Fig. 4. Paclitaxel increased p53 protein expression by 87, 102,812 and $84 \%$ in 10A, 10AT, 10ATG3B and 10CA1a cells, respectively, and induced cleaved PARP fragmentation. Cleaved PARP fragmentation was minimally detected at $48 \mathrm{~h}$ except in $10 \mathrm{~A}$ cells. These results correlated well with hte paclitaxel-mediated induction of apoptosis with the decreased sensitivity in 10CA1a cells (Fig. 2).

Cell cycle-dependent phosphorylation by cdk inhibited $\mathrm{Rb}$ target binding, thus allowing cell-cycle progression (23). The levels of $\mathrm{Rb}$ protein were significantly reduced in each of the cell lines at 24 and $48 \mathrm{~h}$ post-paclitaxel treatment (Fig. 4). The levels of phospho-Rb (Ser780, Ser795 and Ser807/811)
Figure 2. Effects of paclitaxel on cell-cycle progression. The MCF10AT cell lineage was incubated with or without $10 \mathrm{nM}$ paclitaxel for 24 or $48 \mathrm{~h}$ and then fixed with $75 \%$ ethanol and stained with propidium iodide. (A) Histogram of the relative DNA content was determined by flow cytometry. (B) The percentage of cells in each phase of the cell cycle was determined from the histogram.

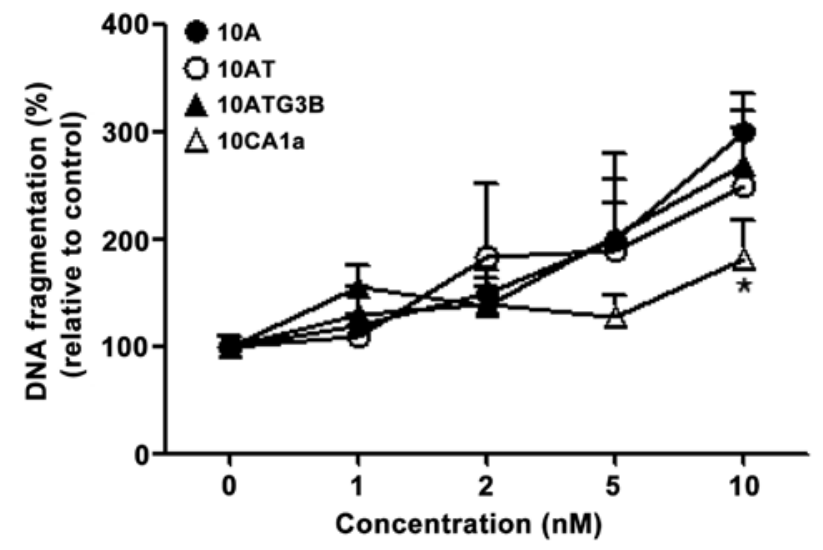

Figure 3. Effects of paclitaxel on DNA fragmentation in the MCF10AT cell lineage. Cells were treated with $0,1,2,5$ and $10 \mathrm{nM}$ of paclitaxel for $24 \mathrm{~h}$. The level of DNA fragments in the cytoplasm was measured by ELISA. The fold induction of DNA fragmentation is shown relative to the value for the control. Data are means \pm standard deviation $(\mathrm{SD})$ of triplicate cultures. *10CA1a cells were significantly different $(\mathrm{P}<0.05)$ to $10 \mathrm{~A}$ cells. 

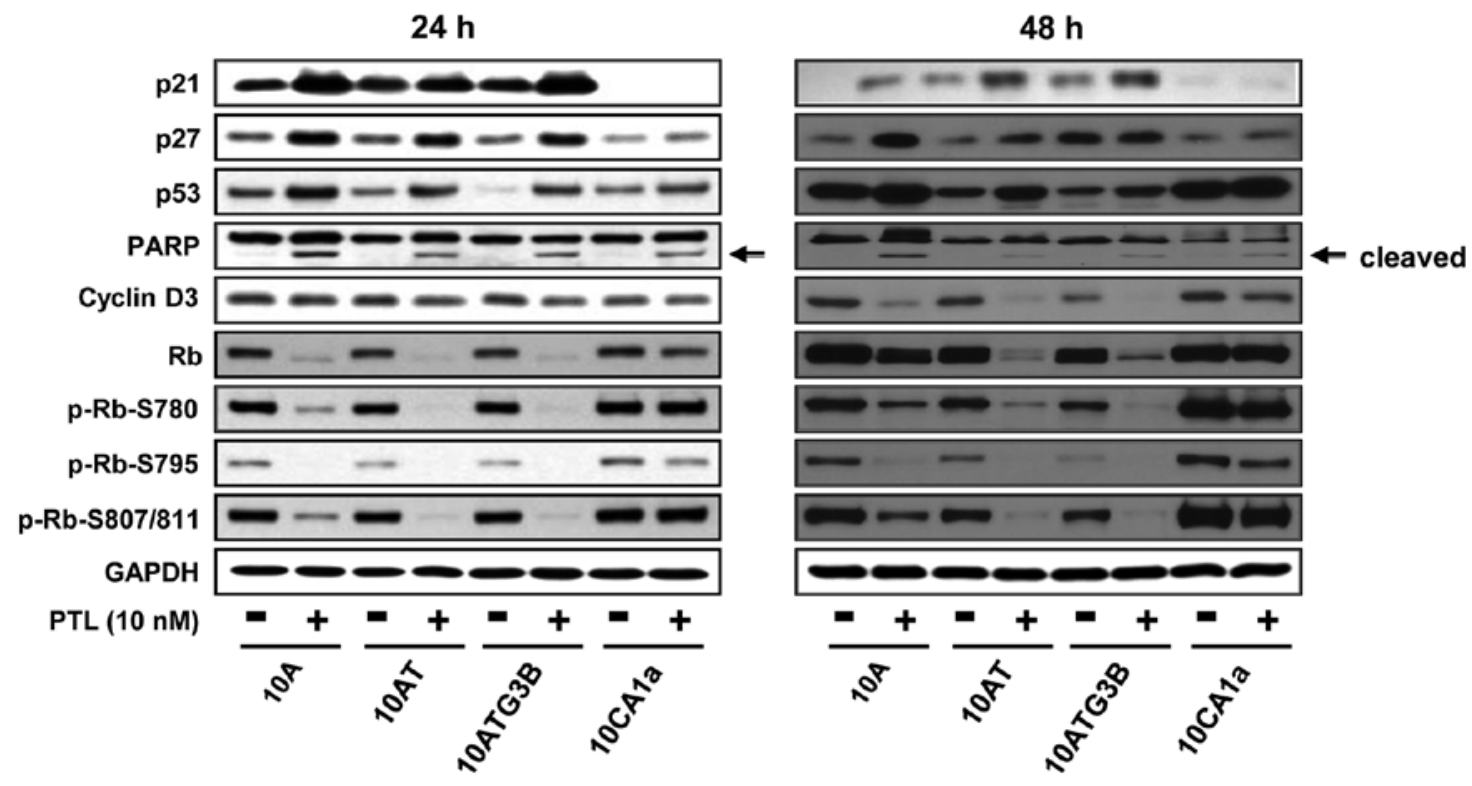

Figure 4. Effects of paclitaxel on the expression of proteins involved in the signaling of apoptosis and $\mathrm{G}_{1}$ cell cycle in the MCF10AT cell lineage. Immunoblot analysis of $\mathrm{p} 21^{\text {Wafl/Cipl }}, \mathrm{p} 27^{\mathrm{Kipl}}, \mathrm{p} 53$, cyclin D3, PARP, Rb and phospho-Rb (Ser780, Ser795 and Ser807/811) protein levels following the treatment of each cell with $10 \mathrm{nM}$ of paclitaxel for 24 and $48 \mathrm{~h}$. GAPDH was used as a loading control. Immunoblot band density was measured by scanning laser densitometry analysis. Rb, retinoblastoma.

A

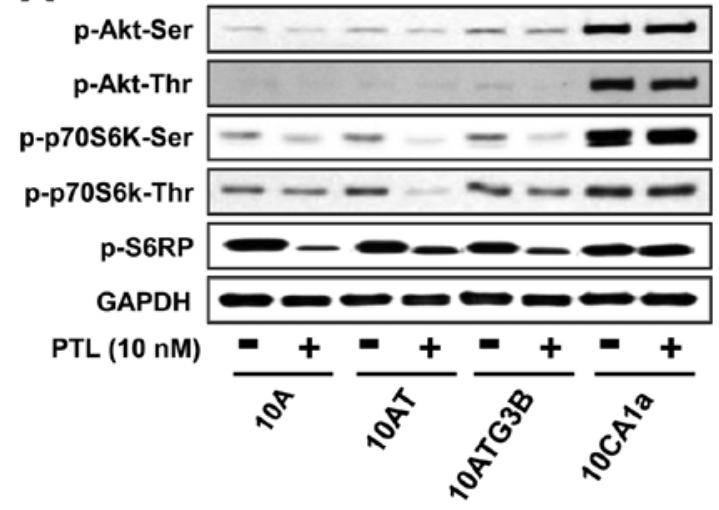

B

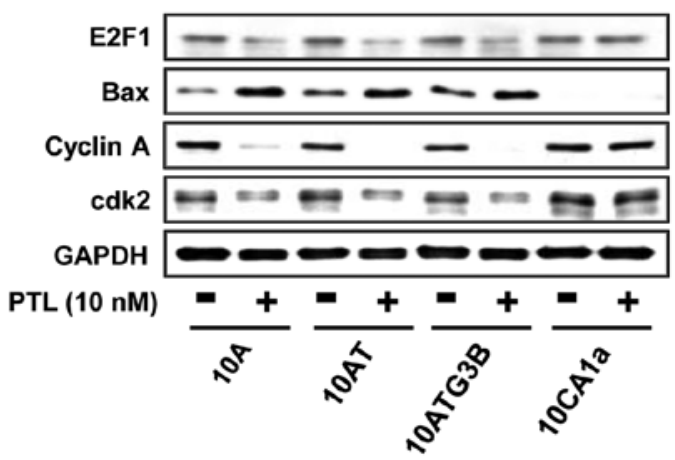

Figure 5. Effects of paclitaxel on the expression of proteins involved in Akt pathway and other apoptosis and $\mathrm{G}_{1}$ cell cycle in the MCF10AT cell lineage. (A) Immunoblot analysis of phospho-Akt, phospho-p70S6K and phospho-S6RP protein levels following the treatment of each cell with $10 \mathrm{nM}$ of paclitaxel for $24 \mathrm{~h}$. (B) E2F1, Bax, cyclin A and cdk2 protein levels following the treatment of each cell with $10 \mathrm{nM}$ of paclitaxel for $24 \mathrm{~h}$. GAPDH was used as a loading control. Immunoblot band density was measured by scanning laser densitometry analysis.

were differentially decreased in the four cell lines at 24 and $48 \mathrm{~h}$ post-paclitaxel treatment, with less decrease in 10CA1a cells (Fig. 4). Paclitaxel increased the cdk inhibitor, p21 $1^{\text {Waf } 1 / \text { Cipl }}$ protein expression in 10A, 10AT and 10ATG3B cells at $24 \mathrm{~h}$ by $2.57-, 1.53$ - and 2.48-fold, respectively, but negligibly in 10CA1a cells at both 24 and 48 h (Fig. 4). p2 $7^{\text {Kip } 1}$ protein, another cdk inhibitor, was also significantly increased in 10A, 10AT, 10ATG3B and 10CA1a cells by 2.73-, 2.22-, 2.40- and 1.71-fold, respectively, post-paclitaxel treatment for $24 \mathrm{~h}$ (Fig. 4). Cyclin D3 levels were minimally changed at $24 \mathrm{~h}$ post-paclitaxel; however, 48-h treatment with paclitaxel effectively reduced cyclin D3 levels in all the cell lines by $11-85 \%$ (Fig. 4). These results supported, in part, that paclitaxel inhibited cell proliferation by $\mathrm{G}_{1} / \mathrm{S}$ cell-cycle arrest in the MCF10AT cell lineage.
Activation of Akt was shown to play a key role in the development of therapeutic resistance (24). The basal protein expression of phospho-Akt (Ser473 and Thr308) was significantly higher in 10CA1a tumor cells (4) and was not inhibited by paclitaxel at $24 \mathrm{~h}$ (Fig. 5A). These phenomena applied to the downstream targets of Akt, i.e., phospho-p70S6K (Thr421/ Ser424 and Thr389) and phospho-S6RP, where paclitaxel inhibited these phospho-proteins efficiently in 10A, 10AT and 10ATG3B cells but not sufficiently in 10CA1a cells (Fig. 5A).

We also observed other proteins involved in apoptosis and the $\mathrm{G}_{1} / \mathrm{S}$ cell-cycle checkpoint, i.e. E2F1, Bax, cyclin A and cdk2. Paclitaxel reduced cdk2 protein levels in 10A, 10AT, 10ATG3B and 10CA1a cells at $24 \mathrm{~h}$ by 55.0, 70.3, 68.2 and $18.2 \%$, respectively, compared to the untreated controls (Fig. 5B). Cyclin A, the binding partner of cdk2 for S-phase 
A

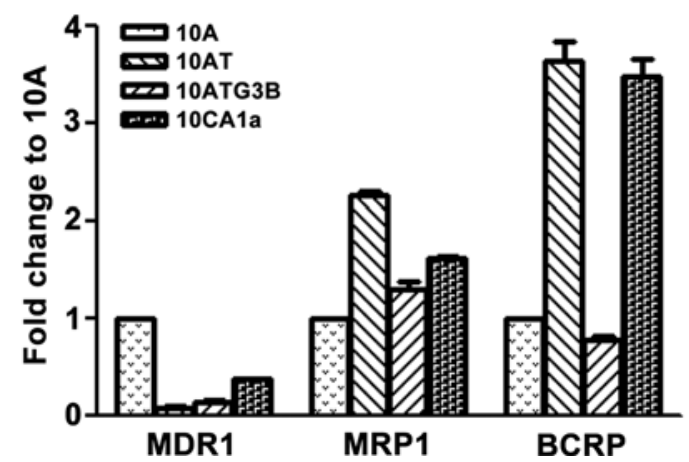

B

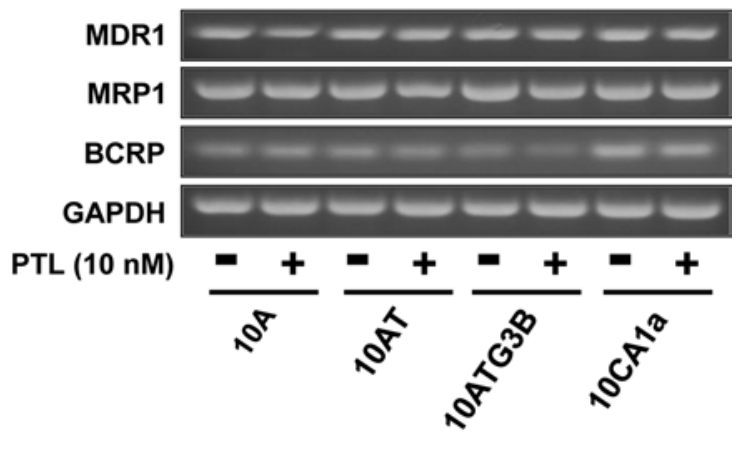

Figure 6. Effects of paclitaxel on $M D R 1, M R P 1$ and $B C R P$ gene expression in the MCF10AT cell lineage. (A) Basal MDR1, MRP1 and BCRP gene expression in the MCF10AT cell lineage was significantly different in each cell of the MCF10AT cell lineage $(\mathrm{P}<0.001)$ except for the comparison between $10 \mathrm{~A}$ vs. 10ATG3B, and 10AT vs. 10CA1a for the expression of $B C R P$. The gene expression of $M D R 1, M R P 1$ and $B C R P$ was determined by quantitative real-time RT-PCR using the StepOne PCR system, with GAPDH as a loading control. (B) Cells were cultured and incubated with or without $10 \mathrm{nM}$ paclitaxel for $24 \mathrm{~h}$. The gene expression of $M D R 1, M R P 1$ and $B C R P$ was determined by semi-quantitative RT-PCR on a $1.5 \%$ agarose gel, with GAPDH as a loading control. $M D R 1$, multidrug resistance $1 ; B C R P$, breast cancer resistance protein.

progression, was inhibited by paclitaxel in the same pattern as cdk2 (Fig. 5B). Transcription factor E2F1 binds preferentially to $\mathrm{Rb}$ in a cell cycle-dependent manner and mediates cell proliferation and apoptosis (25). Paclitaxel reduced E2F1 protein levels in the 10A, 10AT, 10ATG3B and 10CA1a cells at $24 \mathrm{~h}$ by $52.2,55.0,59.9$ and $3.9 \%$, respectively, compared to the untreated controls (Fig. 5B). The apoptosis regulator Bax was upregulated by the tumor suppressor protein $\mathrm{p} 53$ and was found to be involved in the p53-mediated apoptosis (26). The 10A, 10AT and 10ATG3B cells gradually increased basal Bax protein expression and paclitaxel-induced Bax protein; however, Bax was minimally expressed in 10CA1a cells (Fig. 5B).

RT-qPCR analysis. We evaluated the causes of chemoresistance to paclitaxel in 10CA1a cells by measuring the basal expression of multidrug resistance-associated genes in the MCF10AT cell lineage using RT-qPCR. MDRl was significantly decreased $(\mathrm{P}<0.001)$ in 10AT, 10ATG3B and 10CA1a cells. However, MRPI and BCRP gene expression was significantly increased in 10AT and 10CA1a cells compared to benign 10A cells (Fig. 6A). The effects of paclitaxel on the $M D R 1, M R P 1$ and $B C R P$ gene expression were not significant in the MCF10AT cell lineage, with only minimal changes observed at $24 \mathrm{~h}$ (Fig. 6B).

\section{Discussion}

Paclitaxel is an effective treatment of advanced ovarian cancer and metastatic breast cancer in clinical trials. However, loss of sensitivity remains to be clarified. We evaluated the chemotherapeutic efficacy of paclitaxel in the MCF10AT cell lineage, the unique in vitro cell system with progressive tumorigenic potential of breast cancer ranging from benign, premalignant and the fully malignant state $(4,5)$. Paclitaxel-induced inhibition of cell proliferation was progressively decreased in 10A, 10AT, 10ATG3B and 10CA1a cells, and apoptosis and $\mathrm{G}_{1} / \mathrm{S}$-phase cell-cycle arrest were markedly induced in benign and premalignant cells as compared to fully malignant cells, indicating that 10CA1a cells were more resistant or less sensitive to paclitaxel than normal (10A) and less tumorigenic (10AT and 10ATG3B) cells. These results were further confirmed by determining the level of proteins involved in apoptosis and the $\mathrm{G}_{1} / \mathrm{S}$ cell cycle, and the DNA fragmentation assay. Paclitaxel inhibited cdk2, Rb, phospho-Rb and cyclin D3 protein expression and increased PARP fragmentation, p21 Warf1/Cip1, $\mathrm{p} 27^{\mathrm{Kip} 1}$ and p53 at 24 and/or $48 \mathrm{~h}$ with less sensitivity in 10CA1a cells. This finding may be, in part, due to the development of chemoresistance to paclitaxel in 10CA1a tumor cells, which is a common phenomenon in ovarian, pancreatic, bladder, colon and non-small cell lung cancer (24). We examined the causes of chemoresistance to paclitaxel in 10CA1a cells.

Firstly, chemoresistance to paclitaxel is easily developed in various solid tumors, such as colon, ovarian and breast cancers due to overexpression of the $M D R l$ gene which encodes P-gp. Paclitaxel is a representative substrate for $\mathrm{P}-\mathrm{gp}$. Thus, we evaluated the expression of $M D R 1$ and other multidrug resistance-associated genes, MRPI and BCRP, in the MCF10AT cell lineage. $M D R 1$ gene is minimally expressed and $M R P I$ and $B C R P$ were highly expressed in 10AT, 10ATG3B and 10CA1a cells. Our data showed that the basal expression of $M D R l$ gene was unchanged in the MCF10AT cell lineage and $B C R P$ was highly expressed in 10AT and 10CAla cells in the microarray study (data not shown). Immunoblot analysis results also showed that $\mathrm{P}-\mathrm{gp}$ protein was undetected in the MCF10AT cell lineage, yet the BCRP protein was expressed in 10AT, 10ATG3B and 10CA1a cells (data not shown). Furthermore, the gene expression of $M R P I$ and $B C R P$ was not affected by paclitaxel. Therefore, $M D R l$ was not involved in paclitaxel-induced resistance in 10CA1a cells and the high expression of MRPI and BCRP was not associated with chemoresistance to paclitaxel in 10CA1a cells.

Secondly, we examined the basal expression of proteins in the MCF10AT cell lineage in the present study. Notably, the basal expression of p53 was progressively decreased in 10A, 10AT and 10ATG3B cells but increased in 10CA1a cells. Moreover, while p53 was markedly increased by paclitaxel in 10A, 10AT and 10ATG3B cells, it was minimally increased in 10CA1a cells, suggestive of a potential role for $\mathrm{p} 53$ in paclitaxel 
resistance. It was reported that tumors expressing wild-type p53 were less likely to respond to paclitaxel in metastatic breast cancer (27). The study of breast cancer patients with metastatic disease showed that 11 of the 33 patients expressed wild-type p53 and none of the 11 patients with wild-type p53 showed chemoresistance to paclitaxel (28). The role of p53 in chemoresistance is extremely controversial, however, $\mathrm{p} 21^{\text {Waf } 1 / \text { Cip } 1}$ expression was regarded as an important downstream molecule for p53-induced $\mathrm{G}_{1}$ arrest in various types of cancer (29). Our data show that $\mathrm{p} 21^{\text {Waf1/Cip1 }}$ was expressed in 10A, 10AT and 10ATG3B cells and paclitaxel induced p53 and $\mathrm{p} 21^{\text {Waf } 1 / \mathrm{Cip} 1}$, which resulted in strong $\mathrm{G}_{1}$ cell-cycle arrest in 10AT and 10ATG3B premalignant cells. However, p21 ${ }^{\text {Waf1/Cip1 }}$ was minimally expressed in 10CA1a cells, which caused 10CA1a to inefficiently remain in the $G_{1}$ state. Despite any induction of $p 53$, 10CA1a cells did not remain in the $\mathrm{G}_{1}$ phase without $\mathrm{p} 21^{\text {Waf1/Cip1 }}$, as identified in 10AT and 10ATG3B cells. This may have been a cause of unresponsiveness to paclitaxel in 10CA1a cells.

Lastly, the PI3K/Akt signaling pathway phosphorylates molecules downstream from Akt and other effector proteins, including the proapoptotic proteins. Increased activation of the PI3K/Akt signaling pathway in various breast cancers that are associated with PTEN mutations, erbB2 or estrogen-receptor overexpression, promoted breast cancer cell survival and induced resistance to chemotherapy, such as doxorubicin, trastuzumab and paclitaxel (30-32). Ovarian cancer cells overexpressing active Akt/Akt1 were highly resistant to paclitaxel, as compared to cells expressing low Akt levels in different cell lines (33). Previously, it was shown that, phospho-Akt and its downstream molecule, forkhead transcription factors other (FOXO) phosphorylation progressively increased with the increasing tumorigenic potential of the MCF10AT cell lineage. The progressively increasing levels of $H$-ras were suggested as biomarkers of tumorigenic risk from hyperplastic breast tissue (4). High expression of phospho-Akt (Ser473 and Thr308) in fully malignant 10CA1a cells revealed less sensitivity to Akt inhibitors (4) and PI3K inhibitors, wortmanin and LY294002 (data not shown). This resistance was also observed in the MCF10AT cell lineage treated with rapamycin (5). The cell proliferation, $\mathrm{G}_{1} / \mathrm{S}$ cell-cycle arrest and PI3K/Akt signaling protein expression, such as S6RP and p70S6 kinase, and the $\mathrm{G}_{1} / \mathrm{S}$ cell-cycle proteins, such as cyclin $\mathrm{D} 3$, were less responsive to rapamycin in 10CAla cells (5). Notably, the in vitro and in vivo inhibition of the PI3K/Akt pathway by LY294002 reportedly sensitized cancer cells to paclitaxel-induced apoptosis, tumor burden, and the reduction of ascites in ovarian (34), glioma (35) and lung and esophageal (36) cancers. PI3K/Akt inhibitors, i.e., wortmanin and LY294002, enhance microtubule inhibitorinduced apoptosis in vitro (37). Therefore, overactivation of the PI3K/Akt pathway may increase cancer cell survival and induce increased resistance to microtubule inhibitor drugs (24). The potential of targeting this pathway therapeutically is being increasingly investigated $(24,37)$.

Collectively, our results suggest that paclitaxel inhibited cell proliferation and induced apoptosis in the MCF10AT cell lineage, with resistance in the 10CA1a tumor cells. The decreased responsiveness to paclitaxel in 10CA1a tumor cells may be, in part, due to activation of the PI3K/Akt signaling pathway and the high expression of wild-type p53 with a lack of $\mathrm{p} 21^{\text {Waf1/Cipl }}$ in the 10CA1a tumor cells.

\section{Acknowledgements}

This study was supported by the Basic Science Research Program through the National Research Foundation of Korea (NRF) funded by the Ministry of Education, Science and Technology (2009-0066765). We would like to thank Dr Fred Miller and Dr Raymond F. Novak for providing the MCF10AT cell series.

\section{References}

1. Jemal A, Tiwari RC, Murray T, Ghafoor A, Samuels A, Ward E, Feuer EJ and Thun MJ: Cancer statistics. CA Cancer J Clin 54: 8-29, 2004.

2. Dawson PJ, Wolman SR, Tait L, Heppner GH and Miller FR: MCF10AT: a model for the evolution of cancer from proliferative breast disease. Am J Pathol 148: 313-319, 1996.

3. Soule HD, Maloney TM, Wolman SR, Peterson WD Jr, Brenz R, McGrath CM, Russo J, Pauley RJ, Jones RF and Brooks SC: Isolation and characterization of a spontaneously immortalized human breast epithelial cell line, MCF-10. Cancer Res 50: 6075-6086, 1990.

4. Kim SH, Miller FR, Tait L, Zheng J and Novak RF: Proteomic and phosphoproteomic alterations in benign, premalignant and tumor human breast epithelial cells and xenograft lesions: biomarkers of progression. Int J Cancer 124: 2813-2828, 2009.

5. Kim SH, Zukowski K and Novak RF: Rapamycin effects on mTOR signaling in benign, premalignant and malignant human breast epithelial cells. Anticancer Res 29: 1143-1150, 2009.

6. Jordan MA: Mechanism of action of antitumor drugs that interact with microtubules and tubulin. Curr Med Chem Anticancer Agents 2: 1-17, 2002.

7. Guéritte F: General and recent aspects of the chemistry and structure-activity relationships of taxoids. Curr Pharm Des 7: 1229-1249, 2001.

8. Ramanathan B, Jan KY, Chen CH, Hour TC, Yu HJ and Pu YS: Resistance to paclitaxel is proportional to cellular total antioxidant capacity. Cancer Res 65: 8455-8460, 2005.

9. Fuchs DA and Johnson RK: Cytologic evidence that taxol, an antineoplastic agent from Taxus brevifolia, acts as a mitotic spindle poison. Cancer Treat Rep 62: 1819-1222, 1978.

10. Lin HL, Liu TH, Chau GY, Lui WY and Chi CW: Comparison of 2-methoxyestradiol-induced, docetaxel-induced, and paclitaxelinduced apoptosis in hepatoma cells and its correlation with reactive oxygen species. Cancer 89: 983-994, 2000.

11. Dziadyk JM, Sui M, Zhu X and Fan W: Paclitaxel-induced apoptosis may occur without a prior $\mathrm{G}_{2} / \mathrm{M}$-phase arrest. Anticancer Res 24: 27-36, 2004.

12. Zhou $\mathrm{J}$ and Giannakakou P: Targeting microtubules for cancer chemotherapy. Curr Med Chem Anticancer Agents 5: 65-71, 2005.

13. McGrogen BT, Gilmartin B, Carney DN and McCann A: Taxanes, microtubules and chemoresistant breast cancer. Biochim Biohys Acta 1785: 96-132, 2008.

14. Villeneuve DJ, Hembruff SL, Veitch Z, Cecchetto M, Dew WA and Parissenti AM: cDNA microarray analysis of isogenic paclitaxel- and doxorubicin-resistant breast tumor cell lines reveals distinct drug-specific genetic signatures of resistance. Breast Cancer Res Treat 96: 17-39, 2006.

15. Starcevic SL, Elferink C and Novak RF: Progressive resistance to apoptosis in a cell lineage model of human proliferative breast disease. J Natl Cancer Inst 93: 776-782, 2001.

16. Starcevic SL, Diotte NM, Zukowski KL, Cameron MJ and Novak RF: Oxidative DNA damage and repair in a cell lineage model of human proliferative breast disease (PBD). Toxicol Sci 75: 74-81, 2003.

17. Basolo F, Elliott J, Tait L, Chen XQ, Maloney T, Russo IH, Pauley R, Momiki S, Caamano J, Klein-Szanto AJ, et al: Transformation of human breast epithelial cells by c-Ha-ras oncogene. Mol Carcinog 4: 25-35, 1991.

18. Russo J, Tait L and Russo IH: Morphological expression of cell transformation induced by c-Ha-ras oncogene in human breast epithelial cells. J Cell Sci 99: 453-463, 1991. 
19. Santner SJ, Dawson PJ, Tait L, Soule HD, Eliason J, Mohamed AN Wolman SR, Heppner GH and Miller F: Malignant MCF10CA1 cell lines derived from premalignant human breast epithelial MCF10AT cells. Breast Cancer Res Treat 65: 101-110, 2001

20. Liu S, Wu D, Li L, Sun X, Xie W and Li X: NF-кB activation was involved in reactive oxygen species-mediated apoptosis and autophagy in 1-oxoeudesm-11(13)-eno-12,8 $\alpha$-lactone-treated human lung cancer cells. Arch Pharm Res 37: 1039-1052, 2014.

21. Zhan Y, Chen Y, Liu R, Zhang H and Zhang Y: Potentiation of paclitaxel activity by curcumin in human breast cancer cell by modulating apoptosis and inhibiting EGFR signaling. Arch Pharm Res 37: 1086-1095, 2014.

22. Lee EJ, Park MK, Kim HJ, Kang JH, Kim YR, Kang GJ, Byun HJ and Lee $\mathrm{CH}$ : 12-O-Tetradecanoylphorbol-13-acetate induces keratin 8 phosphorylation and reorganization via expression of transglutaminases-2. Biomol Ther 22: 122-128, 2014.

23. Zhang L, Wei Y, Pushel I, Heinze K, Elenbaas J, Henry RW and Arnosti DN: Integrated stability and activity control of the Drosophila Rbf1 retinoblastoma protein. J Biol Chem 289: 24863-24873, 2014

24. Fresno Vara JA, Casado E, de Castro J, Cejas P, Belda-Iniesta C and González-Barón M: PI3K/Akt signaling pathway and cancer. Cancer Treat Rev 30: 193-204, 2004.

25. Kong HJ, Yu HJ, Hong S, Park MJ, Choi YH, An WG, Lee JW and Cheong J: Interaction and functional cooperation of the cancer-amplified transcriptional coactivator activating signal cointegrator-2 and E2F-1 in cell proliferation. Mol Cancer Res 1: 948-958, 2003.

26. Kim CW, Lu JN, Go SI, Jung JH, Yi SM, Jeong JH, Hah YS Han MS, Park JW, Lee WS and Min YJ: p53 restoration can overcome cisplatin resistance through inhibition of Akt as well as induction of Bax. Int J Oncol 43: 1495-1502, 2013.

27. Sezgin C, Karabulut B, Uslu R, Sanli UA, Goksel G, Zekioglu O, Ozdemir N and Goker E: Potential predictive factors for response to weekly paclitaxel treatment in patients with metastatic breast cancer. J Chemother 17: 96-103, 2005.

28. Schmidt M, Bachhuber A, Victor A, Steiner E, Mahlke M, Lehr HA, Pilch H, Weikel W and Knapstein P: p53 expression and resistance against paclitaxel in patients with metastatic breast cancer. J Cancer Res Clin Oncol 129: 295-302, 2003.
29. Waldman T, Kinzler KW and Vogelstein B: p21 is necessary for the p53-mediated $\mathrm{G}_{1}$ arrest in human cancer cells. Cancer Res 55: 5187-5190, 1995

30. Knuefermann C, Lu Y, Liu B, Jin W, Liang K, Wu L, Schmidt M, Mills GB, Mendelsohn J and Fan Z: HER2/PI-3K/Akt activation leads to a multidrug resistance in human breast adenocarcinoma cells. Oncogene 22: 3205-3212, 2003.

31. Clark AS, West K, Streicher S and Dennis PA: Constitutive and inducible Akt activity promotes resistance to chemotherapy, trastuzumab, or tamoxifen in breast cancer cells. Mol Cancer Ther 1: 707-717, 2002.

32. Chang F, Lee JT, Navolanic PM, Steelman LS, Shelton JG, Blalock WL, Franklin RA and McCubrey JA: Involvement of the P13K/Akt pathway in cell cycle progression, apoptosis, and neoplastic transformation: a target for cancer chemotherapy. Leukemia 17: 590-603, 2003.

33. Page C, Lin HJ, Jin Y, Castle VP, Nunez G, Huang M and Lin J: Overexpression of Akt/AKT can modulate chemotherapy-induced apoptosis. Anticancer Res 20: 407-416, 2000.

34. Hu L, Hofmann J, Lu Y, Mills GB and Jaffe RB: Inhibition of phosphatidylinositol 3'-kinase increases efficacy of paclitaxel in in vitro and in vivo ovarian cancer models. Cancer Res 62: 1087-1092, 2002.

35. Shingu T, Yamada K, Hara N, Moritake K, Osago H, Terashima M, Uemura T, Yamasaki T and Tsuchiya M: Synergistic augmentation of antimicrotubule agent-induced cytotoxicity by a phosphoinositide 3-kinase inhibitor in human malignant glioma cells. Cancer Res 63: 4044-4047, 2003.

36. Nguyen DM, Chen GA, Reddy R, Tsai W, Schrump WD, Cole G Jr and Schrump DS: Potentiation of paclitaxel cytotoxicity in lung and esophageal cancer cells by pharmacologic inhibition of the phosphoinositide 3-kinase/protein kinase B (Akt)-mediated signaling pathway. J Thorac Cardiovasc Surg 127: 365-375, 2004.

37. Cheng JQ, Lindsley CW, Cheng GZ, Yang H and Nicosia SV: The Akt/PKB pathway: molecular target for cancer drug discovery. Oncogene 24: 7482-7492, 2005. 